J. Natn. Sci. Coun. Sri Lanka 198311 (2): 277 - 292

\title{
Genesis and Constitution of Sri Lanka Laterites
}

\author{
J. W. HERATH \\ Oceanography Unit, National Aquatic Resources Agency, Colombo 15. \\ AND \\ H. C. N. C. PATHIRANA \\ Geological Survey Department, Colombo 2, Sri Lanka.
}

(Date of receipt : 15 December 1983)

(Date of acceptance : 27 February 1984)

\begin{abstract}
An account is given of the genesis and constitution of Sri Lanka laterites. The warm climate and abundant rainfall alternating with dry periods, favours the development of laterites and lateritic soils in the Island. Lateritic material was examined from coastal areas and inland regions. Majority of the laterites are formed on gneisses of various types, charnockites and granites. It is, however, not possible to identify the parent rock of an individual deposit due to the heterogenity of rocks composing the basement complex. The predominant aluminous mineral in the lateritic materials is the trihydrate, gibbsite $\left(\mathrm{Al}_{2} \mathrm{O}_{3} 3 \mathrm{H}_{2} \mathrm{O}\right)$ or hydragillite and the most common crystalline ferric oxide hydrate is geothite $\left(\mathrm{Fe}_{2} \mathrm{O}_{3} \mathrm{H}_{2} \mathrm{O}\right)$. Aluminous varieties approaching the composition of bauxites are rare. Massive highly ferruginous laterites rich enough in iron hydroxide, mainly goethite (poorly crystallised) to constitute iron ore are common in certain areas of the south-west sector of the Island. It is observed that the laterites of Sri Lanka including the ferruginous varieties are not of any worthwhile commercial importance. They are however, used as a building material (bricks), as clay ochers (specially yellow stains locally named 'samara') and the porous nature of laterites is a highly favourable factor for re-charge of groundwater. The lithomargic clay below the laterite acts as impervious strata and helps in building up the groundwater storage within the laterites.
\end{abstract}

\section{Introduction}

Sri Lanka, because of her warm climate and abundant rainfall alternating with dry periods, favours the development of laterites and lateritic soils. Laterites are well developed in the south-west sector of the Island. A systematic survey of the laterites of Sri Lanka has not been attempted. From time to time studies have been undertaken on various aspects of the material. Laterites have been defined ${ }^{5}$ as a hydrated mixture of oxides of aluminium, iron and titanium of extremely varied composition and showing every gradation from ferruginous laterite almost free from alumina to aluminous laterite almost free from iron. When pure enough to be used as aluminium ore the laterite is generally known as bauxite. This definition adequately covers the most commonly occurring types of laterite in Sri Lanka. It is not proposed here to discuss in detail the lateritic soils of the Island. 
Moorman and Panabokke, ${ }^{12}$ Herath, $7,8,11$ Herath and Pattiarachi ${ }^{9}$, Herath and Grimshaw, ${ }^{10}$ Dissanayake and Vitanage, ${ }^{4}$ Dissanayake, ${ }^{3}$ Dahanayake and Dissanayake $^{2}$ and Dahanayake ${ }^{1}$ have in recent years made valuable contributions on the subject of laterites and lateritic soils of the country. Fernand $0^{6}$ has presented the most detailed account of the Iron Ore Deposits of Ceylon (ferruginous laterites approaching the composition of iron ore). The present communication attempts to discuss the field characteristics of laterite in Sri Lanka and mention is made of the nature and possible origin of the lateritic materials. Many samples collected during geological surveys and drilling operations have been subjected to examination by X'Ray and differential thermal analysis methods. The chemical analysis of a large number of laterite samples has been carried out in the laboratories of the Geological Survey Department. Results of some of the analyses are rep roduced in this paper for purposes of illustration. The main purpose of the present paper is an attempt to summarise the results of laterites examined and to discuss our present knowled.ge of laterites in the Island.

\section{Climate and Geological Setting}

Sri Lanka (Ceylon) is a tropical Island and lies $32 \mathrm{~km}$ to the east of the southernmost extremity of Peninsular India. It has an area of 65,600 square kilometers, and is 432 $\mathrm{km}$ long and $224 \mathrm{~km}$ at its greatest breadth.

The Island may be divided into two main physiographic divisions:-

1. The low lying coastal plain with little relief and traversed by rivers which have reached their base level of erosion in the coastal plain.

2. The central highlands with immature drainage pattern and marked relief abounding in numerous strike ridges, hills and mountains.

The coastal plain is narrow in the western and southern parts of the Island. The general level varies from sea level to about 150 metres and some erosional remnants may rise to 300 metres or more above sea level. The central highlands rise steeply from the coastal plain and the highest mountain (Pidurutalagala) attains an elevation of 2527 metres above sea level.

Sri Lanka lies in the monsoon region of south-east Asia and it has a humid tropical climate. The division into a Wet Zone and Dry Zone which merge in an Intermediate Zone is one of the most widely recognized geographical features of the Island. In Figure 1 the rainfall pattern is shown, clearly demarcating the Wet and Dry Zone. The average rainfall varies from below $127 \mathrm{~cm}$ in the north-west and south-east parts of the lowland zone to over $508 \mathrm{~cm}$ in the south-west slopes of the central hill country. The mean rainfall for the Island is $203 \mathrm{~cm}$. In the Wet Zone areas the average 
mean temperature varies between 70 and $85^{\circ} \mathrm{F}$ and in the Dry Zone it may be nearer $90^{\circ} \mathrm{F}$. In the highlands the mean temperature ranges between $58^{\circ} \mathrm{F}$ and $78^{\circ} \mathrm{F}$ according to elevation.

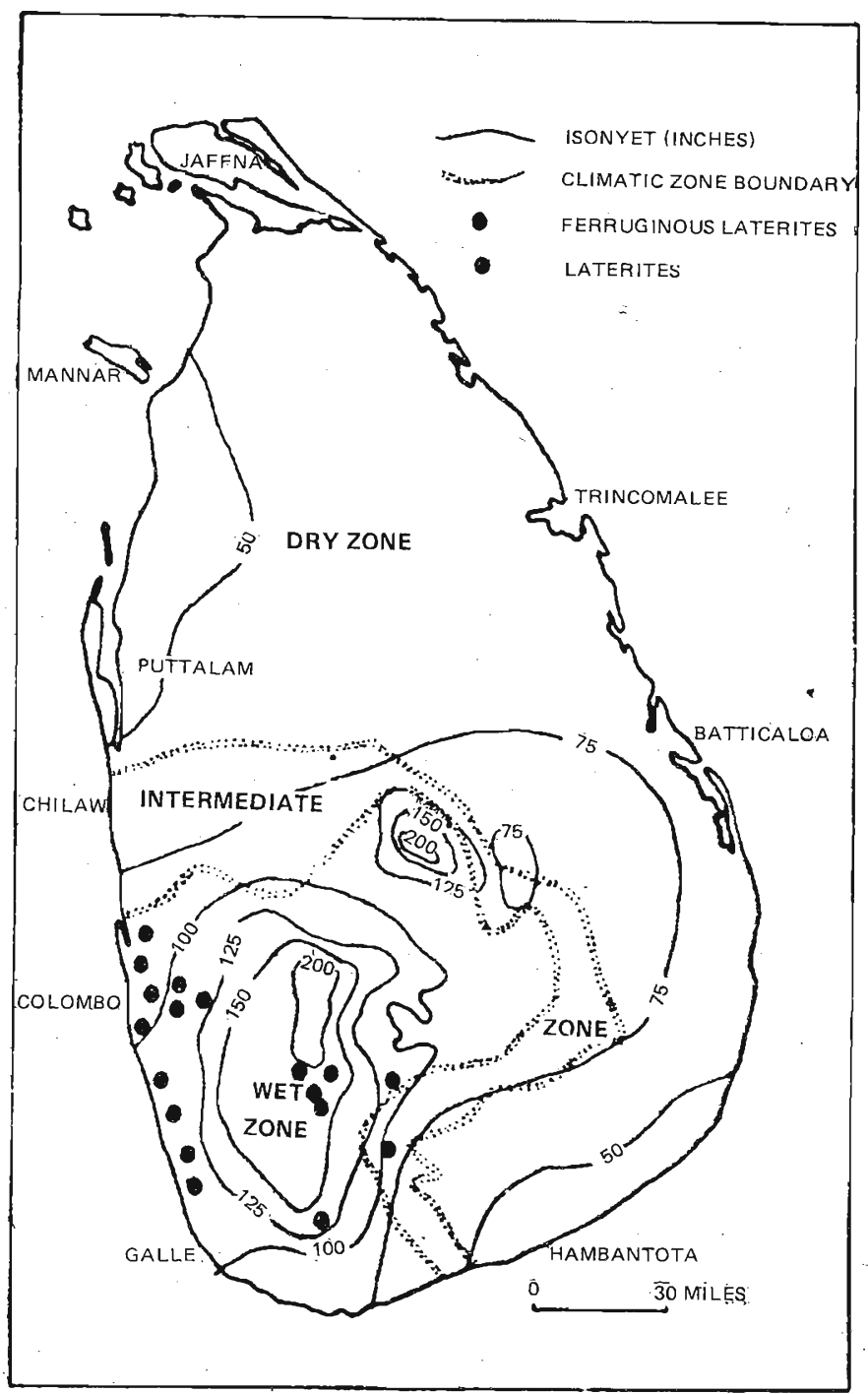

Figure 1. Rainfall pattern in Sri Lanka and Sample Locations. 
The rivers are for the most part radial. The upper reaches are mainly confined to the central hill country. The radial pattern is the dominant element in the drainage pattern of Sri Lanka. The greatest problem of Wet Zone hydrology is that of flood control. Inundation of low lying areas is almost inevitable and vast stretches of ground are subject to serious flooding during the wet seasons. This has resulted in the development of deep and extensive deposits of alluvial material along the lower reaches of the major river systems draining this region. In the Dry Zone it is a seasonal shortage of water which is a problem. Very few rivers rise in the Wet Zone and flow into the Dry Zone.

The main concentration of settlement is in the Wet Zone in the whole of the western, south-western and central hills. In the Dry Zone areas, for example, in the north, north-central and east-central parts of the Island the concentration is slight. The population of Sri Lanka in 1963 (Census of Ceylon 1963 - Department of Census and Statistics) was approximately 11.5 million and in 1971 (Census of Ceylon 1971) the population was 12.7 million. At present it is around 15 million, growing at the rate of 1.7 per cent per annum. About 80 per cent of this population is confined to the rural areas where agriculture is the main activity.

Over 90 per cent of the surface area of the Island is underlain by Pre-Cambrian rocks consisting of a complex series of high-grade metamorphic rocks, most of which have been derived from sediments and altered by one or more metamorphişms. Associated with these metamorphic rocks are granites and granitoid rocks of igneous origin. Figure 2 shows the outcrops of the main geological formations in the Island and Table 1 is presented to show the general succession of geological formations in Sri Lanka.

The Pleistocene deposits which are developed in the western and north-western parts of the Island are mainly gravels and red earths while laterite is mainly developed in the south-west sector of the Island and is clearly a residual deposit. The most extensive sedimentary formation is the Miocene limestone in the north-western area. Rocks of Jurassic age occupy a restricted outcrop area in the north-west. They are shallow water non-marine deposits, consisting mainly of shale and arkosic sandstone. The Pre-Cambrian crystalline complex which covers the major part of the Island consists essentially of three sub-divisions:

1. Highland Series - metasediments and charnockitic rocks.

2. South Western Group - similar to Highland Series but with thin quartzites, wollastonite bearing rocks, cordierite gneisses and chert including coarse charnockites.

3. Vijayan Series - complex of gneisses, granites and migmatites. 


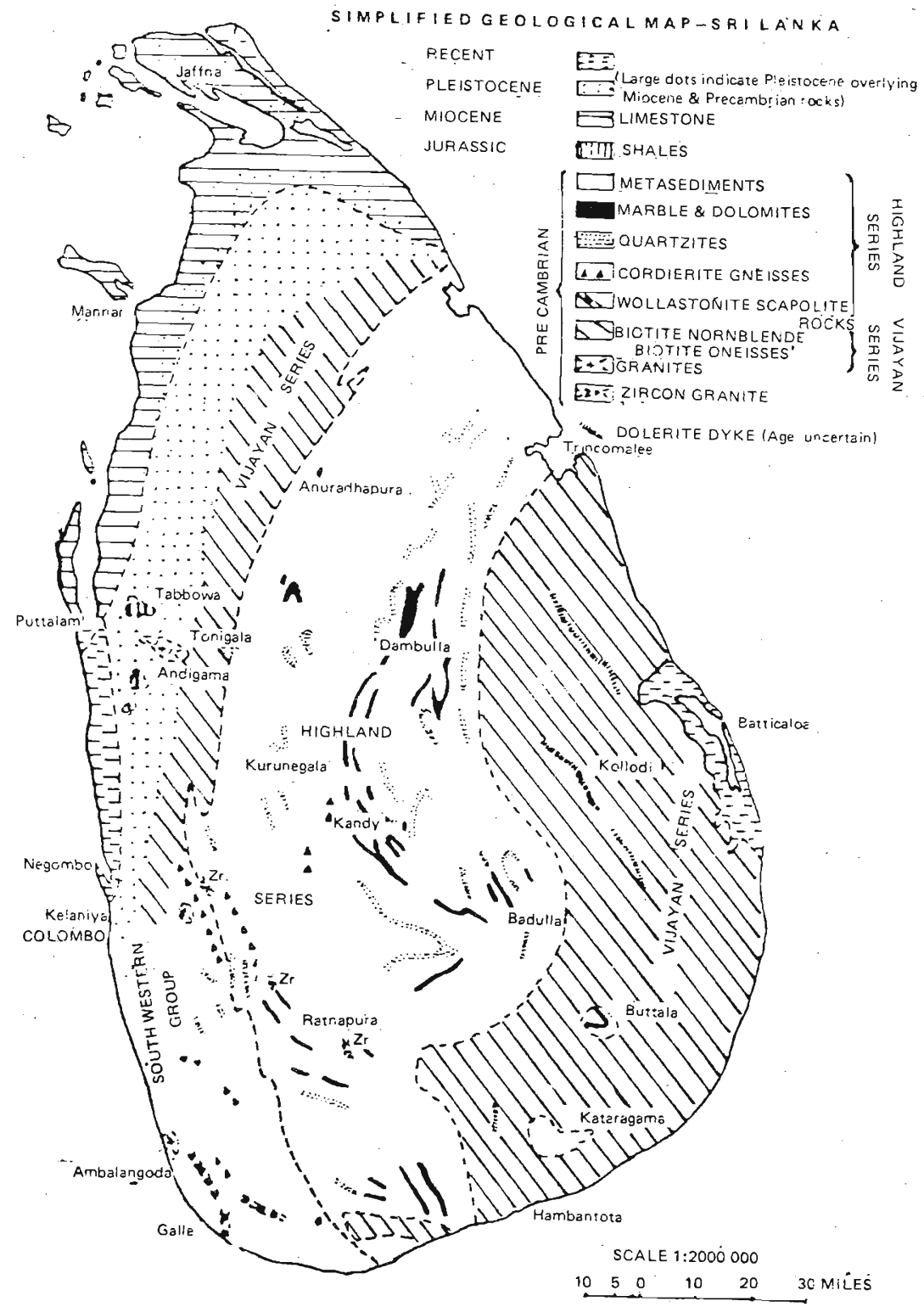

Figure 2. Creological Map of Sri ianka. 
Table 1. General Succession of Geological Formations in Sri Lanka.

Principal Geological

Divisions

\begin{tabular}{|c|c|c|c|}
\hline Era & Period & & \\
\hline ANTHROPOZOIC & $\begin{array}{l}\text { HOLOCENE } \\
\text { (RECENT) }\end{array}$ & $\begin{array}{l}\text { Recent residual and alluvial } \\
\text { deposits, blown sand, coastal } \\
\text { sandstone, coral and shell } \\
\text { formations, beach mineral } \\
\text { sands, gem gravels, lagoonal } \\
\text { \& estuarine deposits, peat. }\end{array}$ & $\begin{array}{l}\text { Kaolin, Ball Clay, Refractory } \\
\text { Bond Clay, Alluvial Clay, Silica } \\
\text { sand, Ilmenite, Rutile, Monazite } \\
\text { Zircon, Baddyleite, Garnet, } \\
\text { Gems, Thorianite, Coral, Shell, } \\
\text { Clay ochers. }\end{array}$ \\
\hline & $\begin{array}{l}\text { (QUATERNARY) } \\
\text { PLEISTOCENE }\end{array}$ & $\begin{array}{l}\text { Laterites (may extend } \\
\text { from recent to Tertiary } \\
\text { Periods) Cravels. Red earths. }\end{array}$ & $\begin{array}{l}\text { Laterites, Limonitic } \\
\text { Iron ore, Red sands. }\end{array}$ \\
\hline CENOZOIC & $\begin{array}{l}\text { TERTIARY) } \\
\text { MIOCENE }\end{array}$ & Limestone. & Limestone. \\
\hline MESOZOIC & JURASSIC & $\begin{array}{l}\text { Shales, Carbonaceous shales } \\
\text { and Arkosic sandstone. }\end{array}$ & Shales. \\
\hline PALAEOZOIC & - & Absent & 一 \\
\hline ARCHAEOZOIC & $\begin{array}{l}\text { PRE- } \\
\text { CAMBRIAN }\end{array}$ & $\begin{array}{l}\text { Highland Series metamor- } \\
\text { phosed sediments. Vijayan } \\
\text { Series gneissic complex } \\
\text { Intrusives granites, dykes } \\
\text { and dolorites. Southwestern } \\
\text { Group. }\end{array}$ & $\begin{array}{l}\text { Serpentinite, Marble, Dolomite. } \\
\text { Magnesite, Quartz, Allanite, } \\
\text { Felspar,Graphite, Mica, } \\
\text { Cordierite Apatite, Chert, } \\
\text { Wollastonite, Sillimanite, } \\
\text { Magnetite, Copper. }\end{array}$ \\
\hline
\end{tabular}

AFTER HERATH 1980 (5)

Rocks, of the Pre-Cambrian complex have been folded into a series of synforms and antiforms, generally trending in a north-west, south-east direction. A good deal of controversy still remains about the nature and indeed of the philosophy of the sub-division of the Sri Lanka Pre-Cambrian. What can be generally agreed however, is that the structures are everywhere complex. 


\section{Nature and Geological Environment of Laterites}

The whole of the Island with the exception of the Jaffna Peninsula and the north-west coast, the Jurassic of Tabbowa and Andigama and small coastal strips elsewhere consists of Pre-Cambrian crystalline rocks. These rocks contain essential quantities of amphiboles, pyroxenes and other ferromagnesium minerals.. Due to prevailing physical and chemical environments the rocks have undergone a lateritic type of weathering. The thickest laterite in Sri Lanka occupies a surface about 30 metres

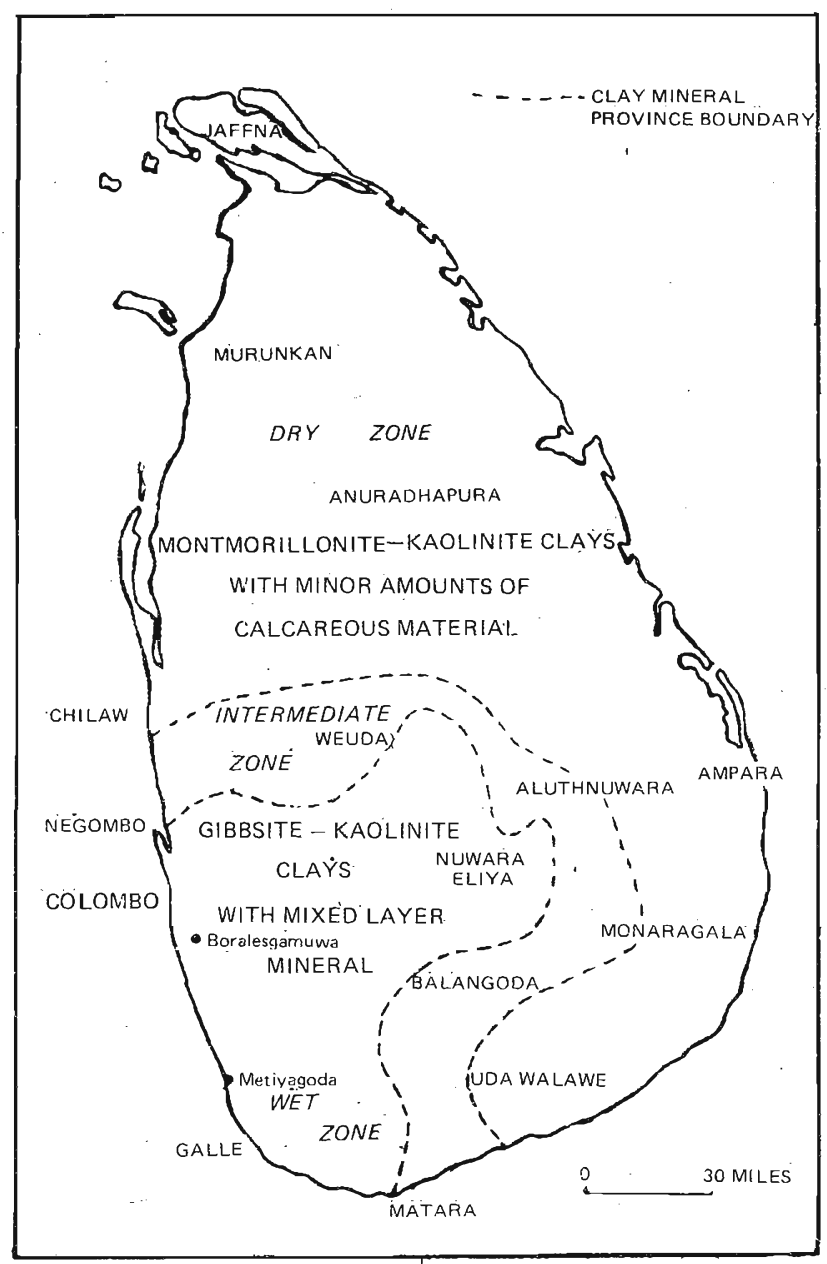

Figure 3. Clay Mineral Provinces - Sri Lanka. 


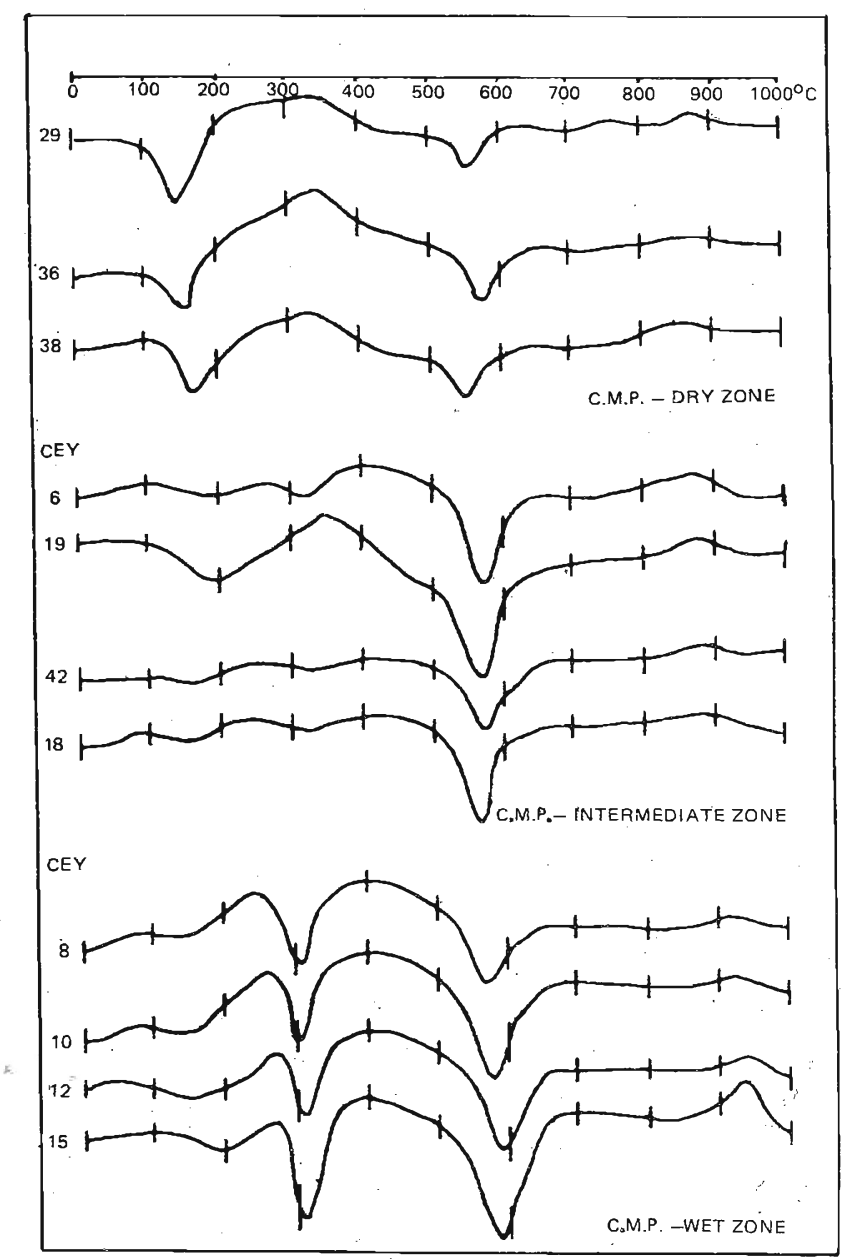

Figure 4. Differential Thermal Curves of the Clay Mineral Provinces.

above sea level between Negombo, north of Colombo and Kalutara south of Colombo. Inland it thins out and with increase of elevation passes into lateritic soils? Figure 3 is presented to show the Clay Mineral Provinces of Sri Lanka.11 The characteristic features of this classification are:-

(a) the progressive development of montmorillonite from wet to dry zone areas; 
(b) the progressive development of gibbsite from dry to wet zone areas and

(c) the progressive disappearance of calcareous material from dry to wet zone areas.

The presence of the mineral gibbsite indicating a lateritic type of weathering, is highly diagnostic and has been used as the main indicator mineral for purposes of this study (see Differential Thermal Analyses Curves Figure 4).

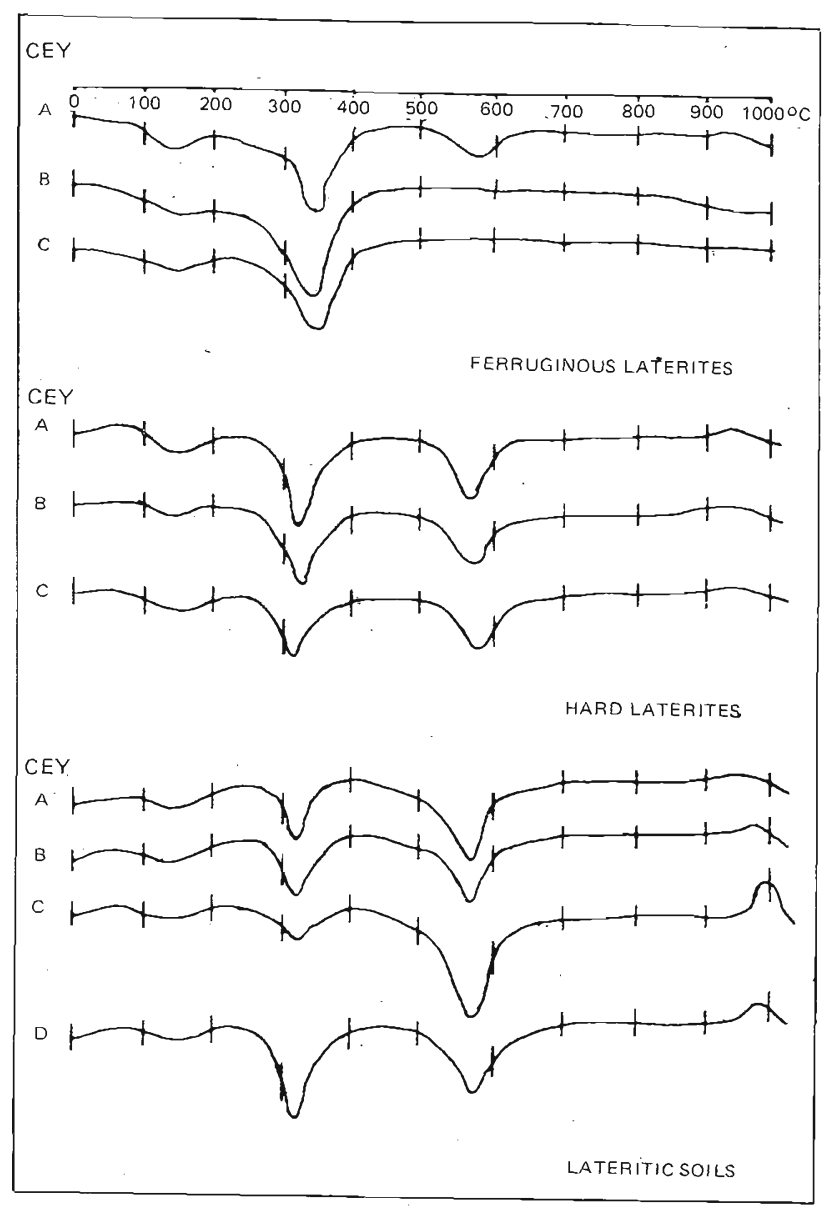

Figure 5. Differential Thermal Analyses Curves of Laterites and Lateritic Soils. 
In Sri Lanka laterites overlie a variety of rock types and are largely laterites developed in situ. The laterites appear to have been more extensively distributed in the south-west low-lands in former geological periods than that which is observed at the present day. Absolute certainty as to the identity of the rock which has given rise to a particular laterite deposit is not always possible as outcrops of rock are rare and the heterogenity of rocks composing the basement complex makes the problem more difficult.

Herath ${ }^{7}$ divided the laterites into 3 broad groups on the basis of differential thermal curves (DTA) Figure 5:

1. Massive highly ferruginous laterites rich enough in iron hydroxide (mainly goethite) to constitute iron ore;

2. Laterites with a vesicular appearance and widely used as a building material (gibbsite - kaolinite or gibbsite and/or goethite - kaolinite mixtures);

3. Lateritic red earths - relatively rich in gibbsite together with goethite and kaolinite. Soils mainly associated with the intermediate slopes and the highlands, (mineralogical composition same as laterites in 2).

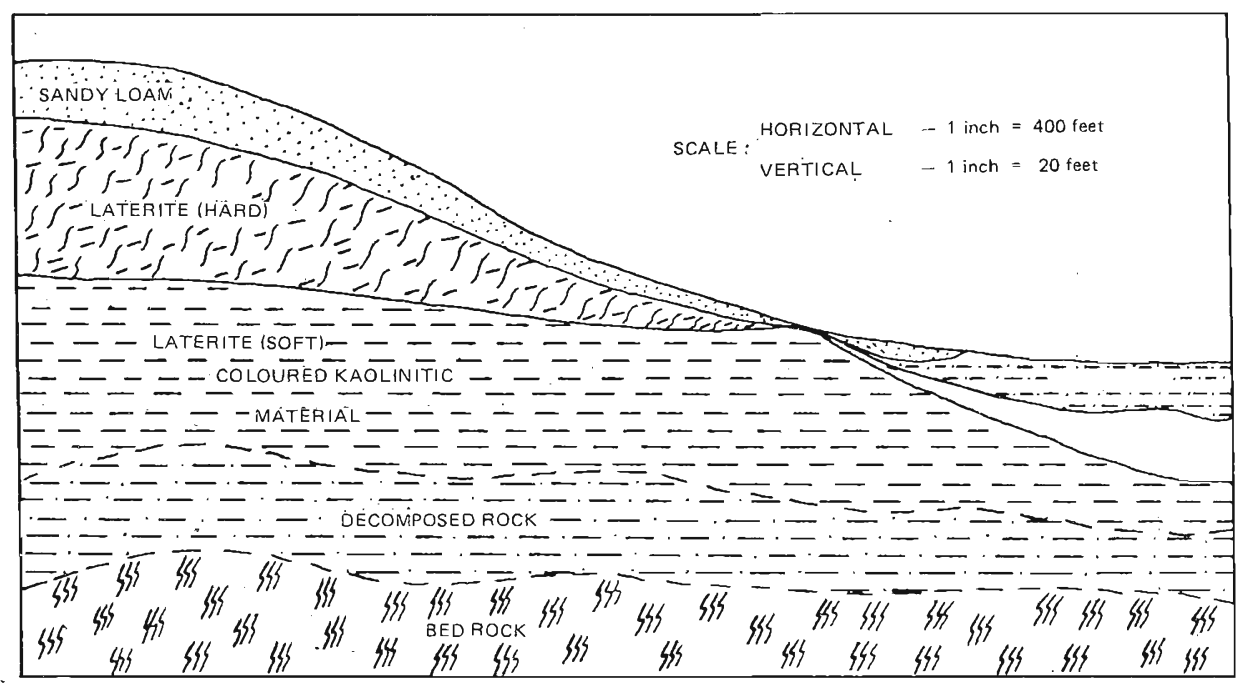

Tigure 6. Diagrammatic Section - Laterite and Kaolin Deposits - Boralesgarruwa. 
The typical laterite is usually separated from its parent rock by a considerable thickness of intermediate decomposition products. The laterite layer may vary in thickness from a few metres to 12 metres or more. The lower beds are soft lithomargelike materials whilst the upper layers are more hard and compact and suitable for building material. In the upper most layers iron oxides get segregated to form surface ferruginous crusts. Normally the laterite layer is close to the present surface. In certain areas the laterite may be buried under varying thickness of later sediments that conceal the lateritization surface. Variations from the typical laterite profile have been observed. The hard laterite layer is normally absent in low lying areas. The soft laterite layer may also be missing. In some parts the soft layer has been almost entirely converted into kaolinite (Figure 6).

\section{Samples Examined and Mineral Determinations}

No systematic studies have been made on the laterites of Sri Lanka. A very large number of samples have been involved in the present sstudy and all the locations of the sampling sites cannot be listed here. A range of typical laterites have been selected from a number of deposits and the lateritic materials are considered representative of the Island as a whole. The selection of the lateritic material was largely based on the changing stages of the weathering profile or on any other physical differences which were visually apparent. The samples collected whilst not representing all the lateritic occurrences of the Island certainly psovide a cross section of those that may be called typical laterites of the Island. The locations of samples examined are presented in Figure 1.

Samples examined:

Ferruginous Laterites

Dela 3, Noragolla 3, Poronuwa 3

Kalawana 4, Rakwana 6, Balangoda 2

Kosgoda 2, Ambalangoda 4, Deniyaya 3.

These samples are mainly the highly ferruginous lateritic types sometimes approaching the composition of iron ore. This ore type is non-crystalline in texture and is comparatively soft and porous. The material occurs as surface cappings and occasionally as embedded lenses or pockets. The cappings are not continuous but consist mainly of detached masses and boulders on the crest of a hill as can be seen at Noragolla, or on hill slopes as at Dela.

The lower grade ores are vesicular, they have a lower specific gravity and contain both clay and siliceous matter.

Samples examined:

laterites

Ragama 6, Hunupitiya 6, Ja-Ela 3, Kalutara 2,

Beruwela 2, Kesbewa 3, Maharagama 2,

Ratmalana 2, Pannipitiya 4. 
These are the typical laterites which could be used to cut bricks for the building industry. The laterites are seen exposed in well cuttings. The lateritic material is purplish or brick red and is porous. It has numerous cavities, filled or partially filled with coloured clay (reddish, yellow or lilac tinted): The sides of the cavities are usually ferruginous. In well exposed areas the hard layers and soft layers of the material can be easily recognized. Wells are sometimes dug in lateritic material of this nature to depths of over 15 metres without any side supporting mechanism. The typical laterites are well exposed around Colombo and the suburbs.

The chemical composition of a number of samples has been determined. X'Ray examination has been undertaken although the method was not suitable for quantitative determinations. The differential thermal analysis method (D.T.A.) was used to gather information on the mineralogy of laterites. In attempting to make a systematic study of a large number of materials it is important to examine the possibility of classifying them into broad mineralogical groups. Type samples from each group can then be selected for detailed examination. The (D.T.A.) method provided a useful technique for a rapid study of lateritic materials.

Results of the examination of Sri Lanka laterites revealed the presence of a number of clay and non-clay minerals, showing a marked similarity, in mineralogical composition. Quartz identified by chemical, X'Ray and D.T.A. niethods was the most prevalent non-clay mineral. Kaolinite as shown by X'Ray, D.T.A。 and the electron microscope was the dominant clay mineral. Halloysite was present in some of the soft lateritic materials while gibbsite (trihydrate of alumina) was invariably associated with goethite (hydrate of iron) and both have been identified by X'Ray, D.T.A. and selective chemical analysis methods. Gibbsite - boehmite bearing soft lateritic materials have also been identified. The main resistant primary minerals identified include, mica, ilmenite and quartz. The clay mineral montmorillonite was not identified in any sample.

For purpose of this study only the typical laterites including the ferruginous varieties (iron ore) are considered. Mention is however, made of lateritic soil where necessary. Table 2 is presented to show the chemical analyses of some ferruginous laterites found in Sri Lanka and Table 3 lists the analyses of some type laterites from the Island.

The ferruginous laterites are mainly composed of the mineral goethite (poorly crystallised), clay minerals are absent. (See Figure 5 for D.T.A. curves). The typical laterites on the other hand are composed of the minerals gibbsite, goethite, kaolinite together with quartz and ilmenite (See Figure 5). D.T.A. curves for laterites (hard laterites) are similar to the D.T.A. curves for lateritic soils developed in the Intermediate slopes and the central highlands of the Island. Mineralogically the two types are similar. It is also interesting to note that gibbsite is totally absent 
Table 2. Chemical Analyses of Ferruginous Laterites.

\begin{tabular}{lrrcc}
\hline & Dela & Noragolla & Ambalangoda & Deniyaya \\
\hline $\mathrm{SiO}_{2}$ & 6.57 & 4.25 & 13.16 & 11.58 \\
$\mathrm{~F}_{2} \mathrm{O}_{3}$ & 73.35 & 80.11 & 64.48 & 69.98 \\
$\mathrm{Al}_{2} \mathrm{O}_{3}$ & 2.10 & 2.22 & 7.99 & 2.15 \\
$\mathrm{Mn}_{\mathrm{TiO}}$ & 1.14 & 0.94 & N.A. & 1.03 \\
$\mathrm{P}_{2} \mathrm{O}_{5}$ & $\mathrm{Trace}$ & Trace & N.A. & 0.15 \\
$\mathrm{CaO}$ & 1.62 & 1.75 & 0.09 & 0.87 \\
$\mathrm{MgO}$ & 0.14 & 0.11 & N.A. & 0.97 \\
$\mathrm{~S}$ & Trace & Trace & N.A. & 0.01 \\
Loss on ignition & 0.17 & 0.19 & N.A. & 0.17 \\
\hline \multicolumn{1}{c}{ TOTAL } & 11.48 & 11.02 & 11.19 & 11.76 \\
\hline
\end{tabular}

Table 3. Chemical Analyses of Laterites.

\begin{tabular}{lrrrrr} 
& RAGAMA & HUNUPITIYA & JA-ELA & MORATUWA & COLOMBO \\
& 46.0 & 47.7 & 41.23 & 46.23 & 42.31 \\
$\mathrm{Fe}_{2} \mathrm{O}_{3}$ & 6.2 & 7.4 & 26.25 & 22.10 & 28.58 \\
$\mathrm{Al}_{2} \mathrm{O}_{3}$ & 36.6 & 32.00 & 20.78 & 20.26 & 19.01 \\
Loss on ignition & 11.0 & 12.00 & 10.20 & 9.25 & 8.76 \\
\hline TOTAL & 99.8 & 98.1 & 98.46 & 97.84 & 98.66 \\
\hline
\end{tabular}

Table 4. Mineralogical Composition of Sri Lanka Laterites.

$\begin{array}{lll}\text { Mineral Group } & \text { Minerals, Invariably Present } & \text { Others } \\ \text { Ferruginous Laterites } & \text { Goethite } & \begin{array}{l}\text { Quartz, Kaolinite } \\ \text { Graphite (flakes) }\end{array} \\ \text { Laterites } & \begin{array}{l}\text { Gibbsite, Goēthite, } \\ \text { Kaolinite, quartz }\end{array} & \begin{array}{l}\text { Other primary resistant minerals } \\ \text { Lateritic Soils }\end{array} \\ & \text { Gibbsite, Goethite, } & \text { Ilmenite, mica, interstratified } \\ & \text { Kaolinite, Quartz } & \text { mineral, vermiculite. }\end{array}$


in dry zone soils (See Figure 4). Table 4 is presented to show the mineralogical constitution of Sri Lanka laterites, the composition of lateritic soils ${ }^{11}$ is also listed in this Table.

\section{Summary and Conclusions}

In Sri Lanka laterites are best developed in and around the Colombo District. It is a residual deposit representing the alteration products of the subjacent granites and gneisses, the genetic connection between the two being clearly evident in numerous exposures where laterite is developed. Field work indicates that the laterites are formed by the alteration of a parent rock in two distinct stages. First, the alteration to a clay material (lithomarge) consisting essentially of hydrated silicate of alumina (kaolinite). This first stage may be conveniently termed Kaolinization. In Sri Lanka kaolinitic formations are invariably present beneath lateritic formations as is well exposed in the Boralesgamuwa area. In low lying areas under swampy conditions the lithomarge is usually converted to beds of pure kaolinitic material which could be used in the ceramic industry (Figure 6). Sri Lanka obtains most of her kaolin from deposits of this nature.

After the first stage of the formation of lithomarge, laterite is formed. This second stage may be termed lateritization which is essentially a desilication process. Laterite is formed by the decomposition of the hydrated silicate of alumina accompanied by the elimination, in solution of the silica which is freed. The residual alumina takes up as much additional water to form the trihydrate of alumina, gibbsite $\left(\mathrm{Al}_{2} \mathrm{O}_{3} 3 \mathrm{H}_{2} \mathrm{O}\right)$. In Sri Lanka this process has not continued to completion and aluminous laterites approaching the composition of bauxites have not been developed. A sample containing 63.5 per cent gibbsite from Nuwara-Eliya has been reported (GEOMINCOHUNGARY), these are isolated pockets of aluminous material and cannot be considered as representative samples from the area.

The ferruginous forms of laterite in Sri Lanka although not extensively developed approaches the composition of iron ores. It has been observed in various parts of the Island that this ore has been used in the indigenous smelting industry in ancient times. The ore is non-crystalline in texture, comparatively soft and porous and occurs largely as surface cappings which are not continuous but consist mainly $/$ as detached masses and boulders on crests of hills or on hill slopes. The iron ore deposits are very small, in point of fact they are insignificant compared to the well known iron ore deposits of the world. The total quantity of ore available is around two million tons, and the material is scattered in over 40 locations over the south-west quadrant of the island.

In Sri Lanka lateritization occurs in the residual soils of a variety of rocks. Lateritic deposits are well developed in the south-west sector of the Island. The predominant aluminous mineral in the soils analysed is the trihydrate gibbsite, the most common ferric oxide hydrate is goethite. The clay mineral is kaolinite. The 
aluminous and ferruginous varieties of laterites are encountered in Sri Lanka. The highly aluminous varieties approaching the composition of bauxite have not been observed to be present in appreciable amounts.

Laterites are used (as cut bricks) in the building industry. The coloured varieties are used as clay ochers and the yellow variety is termed 'samara'. Samara is used extensively in rural areas for colour-washing dwellings. The porous nature of laterite is also a highly favourable factor for re-charge of ground water. The lithomarge clay below the laterite acts as impervious strata and helps in building up the groundwater storage within the laterites.

\section{Acknowledgements}

The Authors wish to thank Mr. L. K. Seneviratne, Director, Geological Survey Department, for permission to use some of the unpublished data of the Geological Survey Department on laterites. X'Ray D.T.A. and electron microscopic studies were carried out at the Houldsworth School of Applied Science, Leeds, U.K. The paper is published with the kind permission of the Chairman, National Aquatic Resources Agency and the Director, Geological Survey, Department.

\section{References}

1. DAHANAYAKE, K. (1982). Laterites of Sri Lanka, a Reconnaissance Study, Mineral Deposits, 17: 245-256.

2. DAHANAYAKE, K. \& DISSANAYAKE C. B. (1979). The distribution and the chemical composition of some laterites of Sri Lanka, Abstr. Inter. Natl. Sem. on Lateritization processes. Trivandram, India 10 .

3. DISSANAYAKE, C. B. (1979). Mineralogy and Chemical composition of some laterites of Sri Lanka Geoderma 23: 147-155.

4. DISSANAYAKE,C. B. \& VITHANAGE, P. W. (1977). Exploration for Bauxites in Sri Lanka, Preliminary investigations, J. .Geol. Soc, India 18: 338-343.

5. FERMOR, (1911). What is Laterite, Geol. Mag. 454-566.

6. FERNANDO, L. J. D. (1964). The Iron Ores of Ceylon (unpublished report), Geological Survey Department (Internal Report).

7. HERATH, J. W. (1963). Kaolin in Ceylon, Ecol. Geol: 58: 769-773.

8. HERATH. J. W. (1963). The Mineralogical Composition of some Laterites and Lateritic Soils of Ceylon, Ind. Mineral. 4: 36-42.

9. HERATH, J. W. \& PATtiaRACHI, D. B. (1963). Geology, Composition and Mineralogy of . Ceylon Laterites, Cey. Geog. 17: 11-20.

10. HERATH. J. W. \& GRIMSHAW, R. W. (1971). A General Evaluation of the Frequency Distribution of Clay and Associated Minerals in the Alluvial Soils of Ceylon, Geoderma 5: 19-30. 
11. HERATH, J. W. (1973). Industrial Clays of Ceylon. Geology, Mineralogy and Appraisal for Ceramics and other industries, Eco. Bull. No. 1. Geological Survey Dept.,61-72.

12. MOORMANN, F. R. \& PANABOKKE, C. R. (1961). A new approach to the identification and classification of the most important soil groups of Ceylon, Trop. Agriculturist, 117: 1-65. 